\title{
Milliyetçiliğe Dair Çözümlemelerde Toplumsal Cinsiyet Olgusu
}

\author{
Alper KASIMOĞLU *
}

\section{Özet}

Millet, milliyetçilik ve etnisite konusundaki hegemonik kuramların çoğu, cinsiyet ilişkilerini konu ile bağlantısı yokmuş gibi ihmal etmiştir. Ancak, son dönemde, toplumsal cinsiyet konusunda yapılan çalışmalar, kadınların, millet ve milliyetçiliğe dair analitik söylemlere nasıl dâhil edildiklerini çözümlemiştir. Milliyetçi projeler toplumsal cinsiyetçi kurgulara dayanmakta, birçok sosyal bilimci bu kurguları çözmeye çalışmakta, ulus ve devletlerin inşasında kadınların varlığını görünmez kılan bakış açılarına karşı itirazlarda bulunmaktadır. $\mathrm{Bu}$ itirazlar, kadına etnik ve ulusal gruplar tarafından yüklenmiş pek çok rolü tartışmaya açmaktadır. Uzun bir süre ihmal edilen milliyetçilik ve toplumsal cinsiyet ilişkisi üzerine farklı disiplinlerde geliştirilen tartışmalardan hareketle, bu ilişkinin incelenmesi ve yapılan çalışmalarının sonuçlarının ortaya konması amacıyla bu çalışma yapılmıştır.

Makalede, Milliyetçilik ve Toplumsal Cinsiyet konusundaki kavramlar ve yapılan çalışmalar metodolojik olarak incelenecektir. Bu kapsamda öncelikle, toplumsal cinsiyet ve milliyetçilik kavramları irdelenmekte ve milliyetçilik kuramlarındaki çözümlemelerde toplumsal cinsiyet faktörü etnik ve milli çerçevede ele alınmaktadır. Milliyetçiliğe dair çözümlemelerde uzun bir süre görmezden gelinen kadınların, milletler ve milliyetçiliklerin inşa süreçlerindeki rolleri ortaya konmuştur.

Anahtar kelimler: Cinsiyet, Toplumsal Cinsiyet, Kadın, Milliyetçilik, Etnik Kimlik

Öğr. Gör., Yalova Üniversitesi, Strateji Geliştirme Daire Başkanlı̆̆ı, İç Kontrol ve Kalite Sorumlusu, kasimoglualper@gmail.com 


\section{The Analysis In The A Bout Nationalism, The Communal Gender Phenomenon's}

Most of the hegemonic theories related to nation, nationalism and ethnicity ignores the gender relations as if they have no connection with the topic. However, recent studies conducted about gender have analysed how women are included in analytic expressions regarding nation and nationalism. Nationalist projects are based on gendered constructions; many social scientists try to untie these constructions and there are objections against the perspectives that ignore the presence of women in the construction of nation and the states. These objections bring many roles that are attributed to women by ethnic and national groups into question. Following the discussions coming up in various disciplines over long-neglected nationalism and gender relation, this study has been conducted to examine this relation and to introduce the results of the conducted studies.

In the essay, studies and concepts regarding Nationalism and Gender will be methodologically analysed. In this regard, the concepts of gender and nationalism are primarily examined and sex factor in the analysis of theories of nationalism is discussed in ethnic and national context. The role of women, who have been ignored in the nationalistic analysis for a long time, in building nations and nationalism has been presented.

Key words: Sex, Gender, Women, Nationalism and Ethnic Identity

\section{Giriş}

Doğumdan itibaren başlayıp yaşam boyu devam eden süreçte, biyolojik cinsiyetten farklı olarak oluşan ve öğrenilmiş davranış kalıplarını içeren toplumsal cinsiyet kavramı, toplumsal bir oluşum olarak (Yıldırmaz, 2005: 9) biyolojik cinsiyetin kültürel düzlemde toplum tarafından sosyal cinsiyete dönüştürülmesini yani, kadınlık ve erkeklik rollerinin oluşturulmasını ifade etmektedir (Akal, 1994:115). Kadın ve erkek cinselliğinin biyolojik özelliklerini yansıtan cinsiyet, gelişim süreci ile beraber kişinin içinde sosyalleştiği toplumun, toplumsal ve kültürel yapısına bağlı olarak toplumsal cinsiyet kimliklerinin kazanılması doğrultusunda bir değişime 
uğrar. Biyolojik ve toplumsal cinsiyet arasında ortaya çıkan bu farklılıklar kadın ve erkeğin farklı toplumlardaki kimliği ve konumu üzerine tartışmalarda belirleyici olmaktadır.

Sosyal bir kurum olarak toplumsal cinsiyet, insanoğlunun yaşamını düzenleyen en önemli yollardan birisidir. Toplumun yüklediği rollerin gelişimi ve sonuçları, dil, din, kanun, bilim ve toplumun tüm değerler grubu tarafından meşrulaştırılmaktadır. Toplumsal cinsiyet kavramını sosyolojiye kazandıran düşünürlerden olan Ann Oakley’e göre "cinsiyet” biyolojik kadın-erkek ayrımını anlatırken "toplumsal cinsiyet" erkeklik ile kadınlık arasında buna paralel ve toplumsal bakımdan eşitsiz bölünmeye gönderme yapmaktadır". (Marshall, 1999: 98).

Çalışmaya konu olan bir diğer kavram olan Milliyetçilik ise onsekizinci yüzyıldan günümüze kadar geçen zaman zarfında yaşadığımız ulus devletler dünyasını temelinden etkileyen bir kavram olmakla birlikte, aynı zamanda üzerinde ortak bir tanıma varılamamış en tartışmalı kavramların başında yer almaktadır.

Milliyetçilik çalışmalarının en fazla üzerinde durduğu konulardan biri de farklı toplumsal grupların milliyetçi projelere ne ölçüde ve nasıl katıldığıdır. Milliyetçi hareketlerin toplumun değişik kesimlerinden destek aldığı biliniyordu; bu bağlamda hareketlerin sınıf profilleri, hareketlere katılanların eğitim düzeyleri, ekonomik ve kültürel durumları en ince ayrıntısına kadar araştırılmıştı. Tüm bunlar yapılırken kadınların milli ve etnik projelere ne şekilde katıldıklarının, onlardan nasıl etkilendiklerinin hiç sorgulanmamış olması son derece şaşırtıcıdır. Milliyetçilik araştırmalarının büyük bir bölümü ( kadınlar tarafından yapılanlar bile ) toplumsal cinsiyet ilişkilerini konuyla ilgili olmadığı gerekçesiyle görmezden geliyordu. Bu eksikliğin farkına ilk varanlar, Kumari Jayawardena, Cynthina Enloe, Floya Anthias ve Nira Yuval - Davis gibi araştırmacılar olmuştur (Özkırıml1, 2008:253)

Bu çalışma ile milliyetçiliğe dair çözümlemelerde uzun bir süre görmezden gelinen toplumsal cinsiyet farklılıklarının ve kadın kimliğinin millet ve milliyetçiliklerin inşa süreçlerindeki önemi, kadınların yalnızca özel alanda iyi bir anne ve eş olmalarının ötesinde, mensubu oldukları mil- 
letin değerlerini ve kültürünü çocuklarına aktarmaları ve "vatana hayırlı evlatlar" yetiştirmeleri yönündeki rolleri ortaya konmaktadır.

Bu kapsamda; makalede, toplumsal cinsiyet ve milliyetçilik konularını birlikte ele alan veya dolaylı olarak bu konularla ilgili olan literatüre dayalı bir tarama, değerlendirme araştırması yapılmıştır. Makalenin ilk bölümünde kavramsal çerçeve çizilip, toplumsal cinsiyet kavramı ve kavrama ilişkin kuramlar, toplumsal cinsiyetin kazandığg önem ve toplumsal cinsiyette farklılık tartışmaları, etnik kimlik, millet, milliyetçilik ve cinsiyet ilişkisi; İkinci bölümde milliyetçilik ve toplumsal cinsiyet ilişkisi ele alınacaktır.

\section{Toplumsal Cinsiyet Kavramına İlişkin Yaklaşımlar}

Cinsiyet kavramına ilişkin yapılan çalışmalarda, yakın zamana kadar biyolojik cinsiyet kavramı ile toplumsal cinsiyet kavramın birbirinden ayıran farklı tanımlamalar bulunmamaktaydı. Bunun sebebi, biyolojik olanla, ona dayandırılarak inşa edilen toplumsal-kültürel cinsiyetin özdeşliğine inanılıyor olmasıydı. Bu özdeşlik inancı, cinslere atfedilen farklı özelliklerin ve bunların gereği olan cinsiyet rollerinin biyolojik, doğal veya ilahi olduğu kanısını desteklemekteydi. Ancak daha sonraki dönemlerde, bedenin kültürel bir varlık olarak kabul görmesi ile birlikte, söz konusu doğallık, tartışmaya açık hale gelmiş; sonuçta cinsiyet ile toplumsal cinsiyet birbirinden farklı iki kavrama dönüşmüştür (Şişman, 2006: 49). Toplumsal cinsiyet kavramı, çeşitli analizlerde, birbirinden farklı anlamlarda kullanılmaktadır. Toplumsal cinsiyetin ne olduğuna ilişkin, teorisyenlerin farklı bakış açıları çerçevesinde, farklı tanımlar ortaya çıkmaktadır. Bun nedenle Zoonen'in dediği gibi, durağan bir özellik taşımayan toplumsal cinsiyetin kategorize edilmesi ve tanımlanması kolay değildir (Zoonen, 1994: 27).

\subsection{Toplumsal Cinsiyet Kavramı}

Başlangıçta sadece gramatik bir nitelik taşıyan toplumsal cinsiyet terimi, günümüzde cinsiyetler arasındaki toplumsal düzenlemelere atıfta 
bulunan bir kavram haline dönüşmüştür. Toplumsal cinsiyet kavramının bugünkü anlamdaki kullanımı 1950'lerde başlamış ve 1980'lerde özellikle feminist hareketin de katkısıyla zirveye taşınmıştır. Bu kavram ilk olarak, cinsiyetler arasındaki farklılıkların toplumsal boyutuna vurgu yapmak amacıyla Amerika'daki feminist hareketin taraftarlarınca kullanılmıştır. Amerika'da kadın sorunları üzerinde araştırma yapan akademisyen ve yazarlar arasında kadın kavramına sınırlı bir anlam yüklenmesini eleştiren bir grup araştırmacı, cinsiyetler arası etkileşimi vurgulamak amacıyla gender (toplumsal cinsiyet) terimini önermiştir. Çünkü onlara göre, kadın ve erkek, ancak birbiriyle bağlantılı ve ilişkili bir şekilde tanımlanabilir. $\mathrm{Bu}$ terimi kullanan akademisyenler, bilimsel disiplinlerin paradigmalarını da sorgulamayı hedefleyince toplumsal cinsiyet kavramı bir anlamda, rrk ve sınıf gibi bir analiz kategorisine dönüşmüştür (Yuval- Davis, 2007: 2730). Söz konusu kavram Türkçe açısından değerlendirildiğinde kavramın, cins, tür ve ırk anlamlarına geldiği anlaşılmaktadır. Cinsiyet ve cinsellik bu kelimenin sonradan kazandığı anlamlardan ikisini oluşturmaktadır (Şişman, 2006:48-49).

Toplumsal cinsiyet kavramı, toplumsal cinsiyet rollerinin dağılımı ve kamusal ya da özel mekânların cinsiyetçi kullanımı etrafında biçimlenir. Feminist hareket, toplumsal cinsiyet rolleri olgusunu iki temel gruba ay1rarak değerlendirmektedir. Bazı feminist araştırmacılar, kadınlık ve erkeklik rolleri arasındaki ayrımın biyolojik temelli olduğunu savunurken, bir diğer grup ise, rol dağılımındaki biyolojik temelleri reddetmemekle birlikte, bu ayrımın öğrenilmiş bir ayrım olduğunu düşünmektedir (Connell, 1998: 78-80).

Toplumsal cinsiyet, kadın ve erkek arasındaki sosyal ve kültürel ilişkilere bağlı olarak yapılandırılmış ve tanımlanmış olup cinslerden her birine yüklenen kimliklere, statülere, rol ve sorumluluklara dayanan ilişkiyi tanımlamaktadır. Toplumsal cinsiyet kavramı, kadın ve erkeğin rollerini, sorumluluklarını, firsatlarını ve ihtiyaçlarını analiz etmeye yarayan sosyo-ekonomik ve kültürel bir değişkendir. Bu terim, sabit ya da doğuştan olmayıp, bireyin sosyalleşme sürecinde anlam kazanmaktadır (Boyarin, 1998: 117). 
Toplumsal cinsiyet kavramı ile ifade edilmek istenen, biyolojik kökenli cinsiyetin tersine, cinsel farklılıkların toplumsal ve kültürel düzlemde yorumlanmasıdır. Bu kavram aynı zamanda tarihsel çözümlemenin birincil kategorilerinden biri olarak görülmüş, her türlü toplumsal ve iktisadi oluşumlarda, siyasal kurumlarda yer eden bir olgu olarak kabul edilmiştir. $\mathrm{Bu}$ nedenle, toplumsal cinsiyet olgusu, her türlü toplumsal sistemin sahip olduğu dinamikleri anlamamıza büyük ölçüde imkân tanımış ve kadınların tarihsel sürece yeniden zorunlu olarak dâhil edilmelerini öngörmüştür (Zilfi, 2000: 29).

\subsection{Toplumsal Cinsiyet Kavramına İlişkin Kuramlar}

Toplumsal cinsiyetin kazanılmasına ve cinsiyetler arası farklılıkların açıklanmasına yönelik farklı kuramlar bulunmakla birlikte; kuramların her biri toplumsal cinsiyete, cinsiyet rollerinin oluşumuna ilişkin farklı bakış açıları ile konuyu açıklamaya çalışmaktadır.

Althusser, Lacan, Foucault, ve Connell gibi düşünürlerin görüşlerini temel alan toplumsal cinsiyet kuramları; dört ana yaklaşım olarak sınıflandırılmaktadır: Toplumsallaşma kuramı, Marksist kuramlar, Psikanalitik kuramlar ve Post-Yapısalcı kuramdir.

\subsubsection{Toplumsallaşma (Sosyalizasyon) Teorisi}

Toplumsal cinsiyetle ilgili literatürde kullanılan en yaygın yaklaşım, “Toplumsallaşma Teorisi'dir". Toplumsallaşma teorisine göre, toplumsal cinsiyetin oluşumu, toplumsal normların öğrenilmesi ve içselleştirilmesine bağlıdır. Birey, içinde doğduğu toplumun kültürünü, değerlerini zamanla içselleştirmekte ve bu sayede doğduğunda sadece biyolojik bir cinsiyeti olan bireyin, zamanla toplumsal cinsiyeti oluşmaktadır. Connell bu sürecin oluşumunu şu şekilde açıklamaktadır : "Çocuk büyürken toplum da çocuğun önüne cinsiyete uygun bir kurallar, şablonlar ya da davranış modelleri dizisi koyar. Belirli toplumsallaştırma etkenleri ya da failleri özellikle aile, medya, arkadaş grupları ve okul-söz konusu bu beklentileri ve modelleri somutlaştırarak çocuğun bunları sahipleneceği ortamı hazır- 
lar. Bu ortamda öğrenme yoluyla çocuk bunları içselleştirir. Bunun sonucunda, normalde belirli bir cinsiyetin toplumsal beklentileriyle örtüşen bir toplumsal cinsiyet kimliği ortaya çıkar (Connell, 1998:255)."

Toplumsallaşma kuramına göre, toplum erkek ve kadına farklı davranış kalıpları biçmektedir. Cinsiyetine uygun davranışları yapan birey ödüllendirilmekte, uygun davranışlar göstermeyen de cezalandırılmaktadır. Örneğin ağlayan erkek, toplumsal yaptırımlarla karşılaşırken, kadın için bu durum olağan karşılanmaktadır. Özellikle anne babalar ve öğretmenler, aynı davranış söz konusu olduğunda kız ve erkek çocuk için fark11 tepkilerde bulunmaktadırlar. Bu durum da insanların erkek ya da dişi olmak üzere iki ayrı davranış kalıbını benimsemesine neden olmaktadır. Toplumsallaşma kuramında, öğrenmenin yanı sıra, model alma da cinsiyet rollerini kazanmanın bir yoludur. Buna göre, genelde kız çocuk annesini model alırken, erkek çocuk babasının davranışlarını model olarak seçmektedir. Öğretmen, arkadaş ya da beğenilen bir ünlü de taklit edilerek cinsiyete uygun davranışlar edinilebilmektedirler. Bu noktada, özellikle kitle iletişim araçlarından televizyon; etkili rol modelleri sunmaktadır.

Toplumsallaşma kuramı özetle, "Biyolojik anlamdaki bir varlık nasıl toplumsal anlamda bir varlık haline geliyor?" sorusuna açıklık getirmeye çalışmakta ve sürecin oluşmasında temel rol oynayan etkenlerin de; bireyin toplumsallaştırılmasından sorumlu olan kurumlar ve insanlar; anne, aile, ögretmenler, arkadaş grupları ve medya; olduğunu ortaya koymaktadir.

\subsubsection{Marksist Teoriler}

Marksist teoriler, genel anlamda kadınların ezilmesinin temel belirleyeni olarak, sınıf ilişkilerini, kapitalist sistemi veya üretim ilişkilerini görmektedir. Marksist analiz kadınların ezilmesini, üretimle ilişkileri (ya da böyle bir ilişkinin olmayışı) bağlamında ele alır. Bu analizler, kadınları işçi sınıfının bir kesimi olarak tanımlayarak, kadınların erkeklerle ilişkisini, işçilerin sermayeyle ilişkisi kapsamında sınıflandırır (Hartmann, 2006: $5)$. 
Kadınların konumu üzerine yapılan çoğu Marksist analizde Hartmann'ın belirttiği gibi, sorun olarak kadınların erkeklerle ilişkisinden ziyade, kadınların ekonomik sistemle ilişkisi ele alınır. Marksist teoride temel sorun ırkçı, etnik ve sınıfsal ayrımların yattığı çatışmalardır ve kadınların ezilmesi sorununun Marksist Devrimden sonra kendiliğinden ortadan kalkacağı varsayılmaktadır. Dolayısıyla cinsiyetçiliğin ortadan kalkmasının birincil koşulu, kapitalizmin ortadan kalkmasıdır.

Kadın sorunu, Marksist teoride Hartmann'ın belirttiği gibi üç çerçevede analiz edilmiştir: İlk dönemde, Marks, Engels, Kautsky ve Lenin gibi Marksistler, kapitalizmin, bütün kadınları ücretli işgücüne kattığını ve bu sürecin cinsiyete dayalı işbölümünü yok ettiğini düşünmüşlerdir. İkinci olarak, Zaretsky gibi çağdaş Marksistler kadınları kapitalizmde gündelik hayatın analizine dâhil etmişlerdir. Üçüncü olarak da Dlla Costa, S. Firestone gibi Marksist feministler, ev işine ve ev işinin sermayeyle ilişkisine odaklanmışlardır. Bunlardan bazıları ev işinin artık-değer ürettiğini ve ev işi emekçilerinin doğrudan kapitalistlere çalıştığını öne sürmüşlerdir (Hartmann, 2006: 5).

Marksist teoriler genel olarak, kadınların cinsiyetçi yaklaşımlara maruz kalmasını, toplumsal konumlarının ikinci planda görülmesini, toplumsal yaşamda ve ev içinde ezilmelerini, sınıf ilişkilerine ve kapitalist sisteme bağlayarak, bu sistemi değiştirmeden kadınların sorunlarının çözümünün mümkün olmadığını ortaya koyarlar.

\subsubsection{Psikanalitik teoriler}

Toplumsal cinsiyetin oluşum sürecine ilişkin olarak geliştirilen ilk yaklaşımlardan biri, Freud'un temellendirdiği psikanalitik kuramdır. Schroeder'in belirttiği gibi, Freud bazı feminist araştırmacılar tarafından "cinsellik sorununu ön plana çıkaran ve cinsel kimliğin biyolojik yaratı1ş̧an kaynaklanmayıp toplumsal olarak oluşturulduğunu ilk savunan kuramc1" (Schroeder, 2007: 67- 68) olarak kabul edilmektedir.

Freud, toplumsal cinsiyetin kazanılmasının üç aşamada gerçekleştiğini belirtir: ilk dönem oral ve anal dönemleri kapsar. İnsan yaşamının bu ilk 
döneminde erkek ve kız çocuklar için toplumsal cinsiyet deneyimleri çok farklı değildir.18 ve 24. Aylarda başlayan ikinci dönem fallik dönemdir. Üçüncü dönemi Freud, ödipal dönem olarak adlandırır. Esas olarak toplumsal cinsiyet rolünün kazanıldığı dönemdir. Freud, ataerkil sistemden yana olan bir düşünürdür ve kuramı, birtakım eleştirilere maruz kalmıştır; fakat yine de psikanalitik kuram, konuya ilişkin önemli açılamalar barındirmaktadır.

Psikanaliz, toplumsal cinsiyetin oluşumunu, normatif kural koymalardan çok iktidar ve gereksinimle karşı karşıya kalmanın etkisi olarak görür. Vurguladığı nokta ise toplumsal bağlam ve kişilik arasındaki süreksizliktir, bunun yanı sıra kişilikteki köklü bölünmelere dikkat çeker ( Connell, 1998:254).

Freud'un kuramını feminist çerçevede yorumlayan Julliet Mitchell, toplumsal cinsiyet oluşum sürecini anlamak için en iyi araçları psikanalizin sunduğunu belirtmiştir. Ona göre psikanaliz, cinsler arasındaki iktidar ilişkilerinin köken ve varlığını ortaya koyan en mükemmel yöntemdir ve psikanaliz ataerkil ilişkilerin meşrulaştırılması için kullanılmamalıdır. Juliet Mitchell, toplumsal cinsiyet temelli öznelliğin ideolojik olarak oluşturulduğunu ve egemen erkek ideolojinin devamlı surette üretilmesini garantileyerek kadınsılığı egemenliği altına alan bir yapı olarak görülebileceğini öne sürer (Schroeder, 2007: 67- 68).

Psikanalitik kuram içinde çeşitli yaklaşımları benimseyen ekoller de vardır. Nancy Chodorow en çok bilinen isimlerden biridir. Dorothy Dinnerstein, Helene Cixous, Luce Irigaray gibi araştırmacılar, toplumsal cinsiyet oluşumunu açıklamakta psikanalitik yöntemi kullanmıştır.

Dorothy Dinnerstein cinsiyetin oluşumu ve aile ilişkileri üzerinde bilinçaltının etkisini araştırmıştır. Cinsel kişiliğin kazanılmasını ve cinsel ilişkilerin kurulup sürdürülmesini anne-çocuk ilişkileri ve bilinçaltının gelişmesi bağlamında ele alıp incelemiştir. Nancy Chodorow sekssizim konusunu öncelikle toplum psikolojisi açısından ele alırken, ailelerin çocuk yetiştirme geleneklerinin cinsiyet ayrımına yol açtığını öne sürer. Ona göre, biyolojik yapılarından dolayı kadınların anne olmaları daha sonra ailenin çocuk bakımı görevini kadına vermesi kızlarda ve oğlanlarda 
psikolojik olarak sanki seksler arasında iş ve kapasite ayrımı varmış gibi bir izlenimin yaratılmasına neden olur. Luce Irigaray'ın kadın tasvirleri üzerine yaptığı çalışma ve Helene Cixous'un kadın yazın kuramı, ataerkil sembolik düzene meydan okur. Irigaray ve Cixous, kadınlar arası farklı11ğın ataerkil sembolik düzen tarafindan temsil edilmediğini ve bu düzenin kanunlarının ve dilinin kadınların yararına hizmet etmediğini iddia eder (Schroeder, 2007: 67).

\subsubsection{Post-Yapısalcı Teoriler}

Post-yapısalcı teori; Derrida, Lacan, Foucault, Deleuze, Irigaray ve Kristeva'nın çalışmalarına dayanan ve bazıları birbiriyle çelişen kuramlardan oluşur. Bu çok boyutlu çalışmalar, "yapıbozma" (deconstruction), "söylem" ve "farklılık" dâhil olmak üzere feminizme kimlik ve öznellik konularındaki geleneksel varsayımlara meydan okumak ve onları tasfiye edebilmek için yararlanabileceği bir dizi eleştirel çerçeve sağlar (Schroeder, 20077: 21). Post yapisalcilar toplumsal cinsiyetin iletilmesi, yorumlanması ve temsilinde dilin merkezi rolüne vurgu yaparlar. Post yapısalcılar "dil" kavramıyla kelimelerden ziyade konuşmanın, okumanın ve yazmanın aktüel hâkimiyetinin önceleyen anlam sistemlerini simgesel düzenleri kastederler.

Toplumsal cinsiyetle ilgili olarak post yapısalcı kuram, "kadın" ve "erkek" gibi kategorilerin doğa tarafindan belirlenmediğini, kültürel ve toplumsal olarak inşa edildiğini ve kültürler ve tarihsel dönemler arasında kayda değer bir değişim gösterdiklerini savunur (Schroeder, 2007: 71). Dolayısıyla, erkek ve kadın kültürleri arasındaki farklılıkların tarihsel olarak üretildiğini savunan bu yaklaşım, öznellik ve kimliğin öze ait ve bütüncül olmaktan ziyade toplumsal olarak inşa edildiğini öne sürerek kavramsallaştırır. Post-yapısalcı kuramcılar, analizlerinde yapı bozmacı yöntemi uygularlar. Post - yapısalcıların toplumsal cinsiyet analizlerinde kullandıkları bu yaklaşım, Derrida'dan alınmıştır. Derrida'nın metinsellik ve okuma üzerine kuramları ve logos-merkezciliğinin ve ikili karşıtlıkların dengesini bozmaya yönelik yaklaşımı, post yapısalcı yaklaşımın temelini oluşturur.

YIL: 5 SAYI: 10 
Toplumsal cinsiyet analizlerine yönelik diğer bir post-yapısalcı yaklaşım da Foucault'nun öznellik, beden, söylem ve güç üzerine çalışmalarını kapsar. Bu yaklaşıma göre cisimleşmiş öznellik, çoğul ama genellikle birbiriyle çelişen öznellik biçimlerini üreten söylemlerin etkisi sonucunda oluşur. Foucault'ya göre psikoloji, biyoloji, tıp, etik, pedagoji gibi söylemler güç odakları ve ilişki ağlarından doğar ki bütün bunlar birlikte genel strateji oluşturur (Schroeder, 2007: 72). Foucault, söylemler dizisi dışında cinsiyet diye bir kavramın varlığını kabul etmez. Foucault'nun çalışmaları, 'ataerkil sistem' ve 'baskı'nın yanı sıra 'kadın' ve 'toplumsal cinsiyet' gibi kategoriler üzerine yapılan feminist araştırmalara da ilham vermiştir.

\subsection{Tarihsel Süreç İçerisinde Toplumsal Cinsiyetin Kazandığı Önem}

Bütün dünyada erkek ve kadın faaliyetlerindeki farklılıklar üzerine son yüzyıl içinde yapılan incelemelerin büyük çoğunluğu, terimin hala bilinmediği zamanlarda bile, egzotik cinsiyet rollerine, ilkele ve geleneksele ilgi duyan gözlemciler tarafından geliştirilmiştir. Sosyologlar insanların ilkel toplumlarda göçebe yasam tarzı içinde avcılık ve toplayıcılık yaparak yaşamlarını sürdürürlerken kadının aile içindeki cinsiyete dayalı is bölümünde önemli roller üstlendiklerini işaret etmektedirler.

Ataerkillikten önce anaerkilliğin yaşandığını ileri süren görüşün temsilcilerinden Boscawen, insanların geçmişte anaerkil soy yasasına sahip olduğunu savunur. Bu savunmasını Babil kadınlarının yaşamlarından aktardığı örneklerle temellendirir. Bu örneklerde kadınlar, kendi mallarının sahibi olup istedikleri gibi onları yönetebiliyorlardı. Babil uygarlı̆̆ında kadın çok yüksek bir konuma sahipti; öyle ki, ana evin tanrıçası anlamına gelen bir kavramla simgelenirdi. Ayrıca anaya karşı işlenen bütün suçların cezası, topluluktan sürülmekti. Bascowen, bu olgunun, insanların bir zamanlar anaerkil soya sahip olduğunun önemli bir kanıtı olduğunu ileri sürmektedir (Stone, 2000: 73).

Feodal toplum yapısının ortaya çıkması sonucunda erkeğin egemenliği ele geçirmesi ile birlikte kadın ikincil plana itilmiş ve toplumsal yapıda önemi azalmıştır. Ataerkil toplum yapısının ortaya çıkışını, değişen tek- 
nolojilere dayandıran açıklamalara göre; teknolojik, toplumsal ve maddi değişimler ağ 1 , kadınlar üzerinde kurulan eril egemenliği de içeren genel anlamdaki egemenlik ve hiyerarşinin ortaya çıkmasını mümkün kılmıştır (Marcos, 2006: 89).

Erkeğin iktidarı ele geçirmesini, mülkiyetin korunması ihtiyacı ile ilişkilendiren anlayışın önde gelen temsilcilerinden Beauvoir, erkeğin sahip olduğu üstünlüğün tabii bir olay olmayıp, gerçekte, ilkel toplumlar arasında cereyan eden sürekli savaşların bir sonucu olduğunu ileri sürmüştür(Beauvoir, 1993: 252). Ona göre, bu savaşlar boyunca erkek, üstün savaşçı rolünü oynamış; sonuçta da bu yeni rolünü, liderliğini korumak amacı ile kullanmıştır. Bu değişim, mülkiyet ve miras haklarında da bir takım değişikliklere yol açmış; erkeğin mülk sahibi olması yanında kalan mirastan büyük pay almasını da sağlamıştır. Bu değişimin sonucu olarak ortaya çıkan durum, kadının toplumda ikincil bir varlık olarak algılanmasina neden olmuştur (Beauvoir, 1993: 254).

Sanayi devrimi ve Fransız ihtilal'ı gibi toplumsal dönüşüm yaratan hareketler kadın algısı ve kadın hakları için önemli gelişmelere neden olmuştur. Sanayi devrimi sonrasında artan iş gücüne duyulan ihtiyaç doğrultusunda kadın evin dışına çıkabilmiş ve ev dışı üretimin bir parçası haline gelmiştir. Bu durum kadının işçi olarak haklarını savunmasından kadın olarak haklarını savunmasına giden süreci başlatmıştır. Kadının kendini ve toplumdaki yerini sorgulayan ve eleştiren sürece girmesinde üretim sistemine dâhil olmasının çok büyük bir etkisi vardır. Sanayi devrimi sonucunda oluşan yeni üretim biçimi, kadınları çalışma yaşamına sokarak, ataerkil toplum yapısında değişime neden olmuştur. Sanayi devriminden sonra ücretli işçi kimliği kazanan kadın, ataerkil sistemin ondan esirgediği diğer hakları da kazanmak için mücadele edebilecekti (Caner,2004:111).

1960'ların sonunda yeni feminizm ortaya çıkana kadar toplumsal cinsiyete yönelik kapsamlı bir ilgi uyanmamış; ilginin uyanmasından sonra görüşlerin merkezini Simone de Beauvoir'ın kadınlara hükmedilmesi sentezi oluşturmuştur. Beauvoir'e göre aşkın projelerdeki erkek tarzının övülmesi sorgulanmalıdır(Connell, 1998: 59). O da bu tarzın genellikle kadınlara ve doğaya hükmedilmesini içerdiğini kabul eder. Kadınların özgürleşmesi ve değişimleri ikincil cins olarak mevcut konumlarındaki 
değişimlerin gerek kamusal gerekse özel alanda görünürlük sağlayarak mevcut durumun kadınların lehine dönüştürebileceği feminist araştırmaların merkezinde yer almaya başlamıştır.

Kadın erkeğin doğasında olmayan, doğuştan gelmeyip sonradan toplumsal yaşantı içinde oluşan farkllılıklar beraberinde toplumsal cinsiyet tartı̧̧malarını da getirmiştir. Toplumsal cinsiyet ile cinsiyet kimliği arasında oluşan farklılıklar, kadın ve erkek arasındaki biyolojik ayrımdan farklı olarak "kadınlık" ve "erkeklik" kategorilerinin toplumsal oluşumu toplumsal cinsiyet kavramını tartı̧̧maların merkezine taşımışıır.

\subsection{Toplumsal Cinsiyet Yaklaşımlarında Farklılık Tartışmaları}

Toplumsal cinsiyet yaklaşımlarında farklılık tartışmalarının tarihi feminist düşüncede 19. yüzyıla kadar dayansa da son otuz yılda eleştirel düşüncenin ve postmodern feminist yaklaşımların "farklılık" kavramını yeni bakış açılarıyla irdelemeleri sonucu "farklılık politikaları" akademik ve politik gündemde ön sıralarda yer almıştır. Özellikle 1970'lerle birlikte, farklılık kavramı artan bir ivme ile daha çok toplumsal gruplar içindeki etnik, sınıfsal, cinsel, ırksal vs. farklılıklara gönderme yapılarak kullanıld. Fakat ikinci dalga feministler, ilk olarak farklılığı siyasal bakımdan hem kadınlar ve erkekler arasında hem de kadınların kendi aralarında bir kutuplaşma olarak aldılar.

İkinci dalga feminizmin öne çıkan düşüncesi olan "ortak baskı deneyimi" aynı zamanda bu hareketin mücadele sınırlarını da çizmiştir. Kadın ve erkek arasında farklılıklara toplumsal cinsiyet ekseninden yaklaşan kimi ikinci dalga feministler kendi aralarında ayrışmıştır. Bazıları, cinsiyetler arasındaki bu farklılı̆̆ın gerçekten var olduğunu, fakat farklılığın kadınları ikincil konuma itemeyeceğini belirtirken, diğerleri ise "besleyen, büyüten, barışçı ve sevgi dolu kadın ahlakının rekabetçi erkekten üstünlüğünü savunmuşlardır ( Daly: 1978, akt. Donovan: 1997:244 ). Bunu yaparken de kadın/erkek, doğa/kültür, kamusal/özel, 1şık/karanlık, beden/ruh gibi kavramsal ikilik setlerini kullanarak cinsiyet farkların dayandırdıkları temelleri yeniden üretmişlerdir (Bora, 2005: 65). Yine de bu dalganın ortak paydası; toplumda kadının konumunu belirleyen hâkim yargıların ataerkil 
sistemin içinden geliştiği ve ataerkil sistemin kadınlar üzerinde önemli bir baskı aygıtı olduğunu belirtmeleridir. $\mathrm{Bu}$ dalga, aynı zamanda, kadının ikincilleştirilmesinin esas alanı olarak aileyi görür. Ataerkilliğin bir cinsiyet rejimi olarak gücünün kendini yeniden üretebilme kapasitesinde yatt1ğını ve bu yeniden üretiminin esasen aile içinde gerçekleştiğini belirtirler.

$\mathrm{Bu}$ yaklaşımlar çerçevesinde postmodernist ve postyapısalcı eleştirilerin feminizmde yankı bulduğu 1980'lerle birlikte siyah kadınlar ataerkil baskı biçimlerinin farklı kadınlar için farklı anlamlar içerdiğini tartışmaya başlamışlardır. Esasında siyah kadın hareketinin ilk tohumları 1830'lu yıllarda atılmıştır. Maria W. Stewart, Afrika Kökenli Amerikalı kadınların 1rkçı ve cinsiyetçi baskıya karşı politik mücadeleye çă̆ırır. Stewart, siyah kadınların kendi hayatlarında söz sahibi olmalarının en önemli koşullarından biri olarak siyah kadınlarının birbirleriyle politik ilişki içinde olmaları gerektiğini iddia etmiştir (Wise ve Stanley, 1990:80 ).1960'lara gelindiğinde, birçok siyah kadının feminizm ile tanışması, siyah kadınların insan hakları hareketi içinde ikinci sınıf vatandaşlar olarak muamele gördüklerinin farkına varmaları ile gerçekleşir.

Kadın özgürlük hareketi içindeki siyah feministler, beyaz kadının üstün, siyah kadının ikincil sayıldığı kültürel kavramların ve ırkçı inanç ve uygulamaların meşrulaştırılmasına yönelik politikaların oluşturduğu yapıları öncelikle eleştirdiler. Irksal ve etnik azınlık hiyerarşilerinin doğal görülmesine yönelik uygulamalara dikkat çektiler. Siyah feministler, siyah kadının "ötekilik" ini vurguladılar. Siyah feminizmde "ötekilik" incelendiğinde; siyah bir kadın ve feminist olmak farklı olmak anlamına gelmektedir. Siyah olmak beyaz, ırkçı toplumun dışında durmakken, feminist olmak kendini siyah toplum - erkek ve diğer feminist olmayan - için "öteki" k1lmaktır (Wise ve Stanley, 1990:89).

\section{Milliyetçilik}

Milliyetçilik, milli hisse dayalı duygu, davranış tarzı ve tutumlar anlamında oldukça eskilere götürülebilse de; bir ideoloji veya siyasi hareket olarak modern dönemlere ait bir olgudur. Bu haliyle milliyetçiliğin, son iki asır zarfında dünyanın ulus esaslı olarak düzen kazanmasında, bir siyasi

YIL: 5 SAYI: 10 
örgütlenme biçimi olarak ulus-devlet modelinin ortaya çıkıp evrenselleşmesinde ve yaşanan uluslaşma süreçlerinde başrolü oynadığı söylenebilir.

Milliyetçilik bir ideoloji olarak Sanayi Devrimi'nden sonra Bat1 Avrupa'da ortaya çıkmıştır. Sanayi Devrimini gerçekleştiren ülkelerde, XV. yüzyıldan beri yaşanmakta olan toplumsal değişim süreci (modernleşme) hızlanmış, oluşan yeni kolektif ihtiyaçlar neticesinde sosyal ve siyasi alanda ön plana çıkan başlıca ideoloji milliyetçilik olmuştur (Smith, 2001: 46, 47).

E.J. Hobsbawm'a göre milliyetçilik önce kültürel, edebi bir mahiyete sahiptir. Sonra politik aktörler tarafından politik bir programa dönüştürülür. Üçüncü ve sonuncu olarak ise kitlesel destek elde ederek iktidar oyununun değişmez bir parçası halini alır (Hobsbawm, 1995:96). A. Smiht ise milliyetçiliğin, sadece bir toplumsal hareket türü ve bir siyasal ideoloji değil, aynı zamanda bir "kültür" biçimi ve "bir kültür/kimlik biçimi olarak" incelenmesi gerektiğini ifade etmektedir (Smith, 2001, s.118).

Kellas'a göre, müşahede edilen milliyetçilik tipleri şöyle özetlenebilir (Kellas, 1991:51):

Etnik milliyetçilik; milletlerini zümre terimleriyle adlandırmakta ve doğuştan bu özelliklere sahip olmayanı dişlamaktadırlar. Genellikle ortak ırk özelliklerine dayalıdır. Bu tür milliyetçilikte dışarıdan bir kimse gurup kültürüne adapte olamadığı gibi guruba da üye olamaz.

Sosyal milliyetçilik; Kendini sosyal bağlarla ve ortak kültürle tarif eden bir milletin milliyetçiliğidir. Ortak millî kimlik, topluluk ve kültür vurgulanır; dışarıdan herhangi bir fert her zaman bu unsurları kabul ettiğinde milletle bütünleşebilir. Irk ayniyeti şart değildir. Etnik milliyetçiliğin dışlayıcı özellikler arz etmesine karşılık sosyal milliyetçilik kapsayıcıdır.

Milliyetçilik tarihin en eski ayırımı olan biz ve onlar ayırımının ulus devletler ve ideolojiler çağındaki karşılığı olmuştur. Bir bütüne (biz’e / millete) ait olma bilinci milletleşme sürecinin ve dolayısıyla ulus devletleşme sürecinin temel dinamiğidir. Bu bakımdan milliyetçiliğin tanımlanabilmesi için öncelikle etnik kimlik ve millet kavramlarının açıklanması gerekmektedir. 
256 - YALOVA SOSYAL BILIMLER DERGISI

\subsection{Etnik Kimlik}

Etnik kimlik, bir devlet içinde egemen/başat çoğunluk dışında kalan, kendini farklı gören ve düşünen, birbirlerine çeşitli bağlarla bağlı oldukları iddiasıyla, millet ve milliyetçilikte olduğu gibi kan bağı, dil, din, tarih birliği (Heckmann, 2009: 84) gibi duygusal bağlarla bir araya gelmiş olan insanların oluşturdukları birliktir. Smith (1994: 42) etnik bir topluluğun, kollektif özel bir ad, ortak bir soy miti, paylaşılan tarihi anılar, ortak kültürü farklı kılan bir ya da daha fazla unsur, özel bir "yurt" la bağ ve nüfusun önemli kesimleri arasında dayanışma duygusu olarak tanımladığı altı niteliği olduğunu belirtir. Bu nitelikler doğrultusunda etnik gruplar kendilerine özgü duygu ve düşüncelere sahip toplumdaki nüfusun farklı bir kategorisi olarak kendilerini görürler. Ayata etnik grubu şöyle değerlendirir: Her etnik grup, farklılığını korumak için, kendini diğerlerinden ayıran farklılıkları tanımlamak zorundadır. Bütün etnik cemaatlerin kendi grupları içinde tipik olan "kabul edilebilir" olanı, "anormal" olanı ve beklenen tutum ve davranış biçimlerini tanımlamaları gerekmektedir. Bu, gruba özgü olan kültürel esasların bir parçasıdır (Ayata, 1996: 197).

Yuval-Davis (2007: 92), etnisitenin, topluluk sınırları politikası ile bağlantılı olduğunu ve kimlik anlatılarını kullanarak dünyayı "biz" ve “onlar” arasında böldügünü belirtir. Etnik projelerin ise, topluluklar içindeki belli konumlanışlardan, topluluğu destekleme veya onun avantajlarını devlet ve sivil toplum güçlerine erişim aracılığıyla sürdürme amaçlı mücadeleye ve müzakere süreçlerine sürekli katıldıklarını belirtir. Yazar, etnisiteyi tanımladıktan sonra değerlendirmesine şöyle devam eder: $\mathrm{Bu}$ tanıma göre etnisite, sadece topluluğun toplumdaki ötekilerle bağlantılı genel konumlanışının değil, aynı zamanda da "etnik politika" ya girişenlerin o topluluk içindeki ötekilerle belli ilişkilerinin sonucu olarak, topluluğu ve "onun çıkarları" nı kuran, temelde siyasi bir süreçtir. Toplumsal cinsiyete ve sınıfa dayalı ayrımlar, siyasi, dini ve öteki farklılıklar, özgül bir etnik siyasetin kuruluşunda merkezi rol oynamaktadır (Yuval - Davis, 2007: 92).

YIL: 5 SAYI: 10 


\subsection{Millet Kavramı}

Milleti oluşturan özellikler, zaman içerisinde değişime uğrayabildikleri gibi, aynı zamanda içinde biçimlendikleri tarihsel ve toplumsal koşulların etkisi altında farklı şekillerde kendini göstermektedir. Bu nedenle millet kavramının, içerdiği tüm öğeleri kapsayan, kendisine dışarıdan herhangi bir ekleme yapılamayan ya da kendisinden herhangi bir şey çıkarılamayan, değişmez ve mutlak bir tanımını yapmak pek mümkün değildir.

18. yüzy1l öncesinde belli nitelikteki bir topluluğu tanımlamak için kullanılan millet kavramı, siyasî düzen açısından da herhangi bir anlam ifade etmezken, Fransız İhtilâli ile birlikte siyaset bilimi literatürüne girmiş ve siyasî bir anlam kazanmıştır.

Millet olgusu, tanımlamalarda ağırlık verilen unsura göre çeşitlilik sunan, dinamik ve çok boyutlu bir olgudur. Millet tanımlarında ele alınan unsurların ağırlığına göre farklı görüşler dile getirilmiştir. Bazılarına göre din, dil, 1rk gibi "nesnel” öğeler ön plandayken, kimilerine göre millet olma bilinci, bağlılık duygusu, beraber yaşama iradesi gibi “öznel” öğeler ön planda yer almıştır. Yine farklı bir yaklaşıma göre: "sosyal-kültürel" öğeler, yani dil, gelenek-görenekler, tarihî semboller ve kahramanlar, zaferler ve yenilgiler, ortak duygu ve değerler millet olmanın temel şartı iken diğer bir yaklaşıma göre: "sosyo-politik" öğeler, yani vatandaşlık, ortak yönetim sistemi -devlet, ekonomik ilişkiler, coğrafya- gibi unsurlar milletin temel öğeleri arasında sayılmıştır.

$\mathrm{Bu}$ alanda önemli çalışmalara imza atan Anthony D. Smith milleti, tarihten gelen bir toprak parçasını/ülkeyi, topluluğun ortak mitlerini ve tarihsel belleğini, kitlesel bir kamusal kültürü, ortak bir ekonomiyi, ortak yasal hak ve görevleri paylaşan bir insan topluluğunun adı olarak tanımlarken, (Smith, 1999:32) millet olmanın olmazsa olmaz şartlarını, ortak soy ve köken, ortak tarihî bellek ve etnik göstergeler olarak belirtmiştir (Smith, 1999:115). Gökalp de milleti, "dilce, dince, ahlâkça ve bediiyatça [güzel sanatlarca] müşterek olan, yani aynı terbiyeyi almış fertlerden mürekkep bulunan bir zümredir" (Gökalp, 2004:18) şeklinde tanımlamıştır. 


\section{$258 \cdot$ YALOVA SOSYAL BILIMLER DERGISI}

\subsection{Milliyetçilik ve Cinsellik}

Milliyetçiliğin farklı bir boyutu ise cinsellikle kurduğu ilişkidir. Cinsellik ile milliyetçilik arasındaki ilişki "namus" kavramıyla yakından bağlıdır. Najmabadi’ye göre, "namus”, "ulusun erkek oluşu ile vatanın kadın oluşuna sıkı sıkıya bağlı olan bir kavramdır" (Najmabadi, 2009: 130). Najmabadi, vatanın, hem erkek arzusunun yöneldiği, hem de erkeğin koruyup sahiplendiği bir kadın figürü olarak kurulduğunu belirtir. Yazar, kadın bedenine sahip vatanın, kadınlar için farklı bir beden ürettiğini ve annelik kavramlarının yeniden oluşturulmasında rol oynadığını belirtir (Najmabadi, 2009: 133), "Sevgili ve anne olarak vatan, kadın kavramlarını değiştirerek yeni kadınlıklar, yeni erkeklikler doğurdu”. Najmadadi şöyle devam eder: "Kadın vatanı korumakla yükümlü bir erkekler topluluğu olarak modern devlet, simgesel düzeyde de giderek daha fazla erkekleştirildi. Vatan, korunan bir kadın kategorisine iyiden iyiye sokuldukça, devlette o ölçüde koruyucu erkek niteliği kazandı" (Najmabadi, 2009: 154), Najmabadi, aynı zamanda, ailenin hem bir kurum hem de bir metafor olarak çeşitli milliyetçilik kurgularının ve ulus devlet pratiklerinin merkezinde yer aldığını belirtir.

Nagel ise, milliyetçiliğin tanımı gereği siyasal olduğunu, devletle ve onun kurumlarıyla bağlantılı olduğunu belirtir. Ordu gibi çoğu devlet kurumlarının gerek geçmişte gerekse günümüzde erkeklerin hâkim olduğu alanlar olduğunu ve bu nedenle de hegemonik erkeklik kültürü ve ideolojisinin hegemonik milliyetçilik kültürü ve ideolojisiyle el ele gitmesini şaşırtıcı bulmaz (Nagel, 2009: 78). Nagel, erkeklik ve milliyetçilik arasındaki yakın bağın, tüm hegemonik yapılarda olduğu gibi, yalnızca erkeklerin duygu ve düşüncelerini biçimlendirmekle kalmadığını kadınların da zihinlerine ve yüreklerine damgasını vurduğunu belirtir (Nagel, 2009: 97).

\section{Milliyetçilik Ve Toplumsal Cinsiyet İlişkisi}

Modernist milliyetçilik kuramcılarının hepsi, özellikle feminist araştırmacılar tarafından, milletler ve milliyetçiliklerin inşa süreçlerini incelerken kadınları görmezden gelmekle eleştirildiler. Feminist araştırmacılar bu eksikliğin giderilmesi için cinsiyet ve millet konusundaki söylemlerin

YIL: 5 SAYI: 10 
kesişme eğilimlerinin ve bunların birbirleri tarafindan kurgulanma biçimlerinin incelenmesi gerektiğini vurguladılar (Çağlayan, 2007:22). Bu yönelim milli kimlik inşası ve milliyetçi ideoloji içerisindeki kadınların konumunu görünür kılma çabasının da ötesinde, toplumsal cinsiyet ilişkilerinin milliyetçilik gibi politik projelerin önemli kurucu unsurlarından biri olduğunu gösterdi. Çağlayana göre "etnik/ulusal kimlikleri, toplumsal cinsiyet kurgusu açısından inceleyen çalışmalar, topluluk adına söz söyleme ve onu temsil etme konumundakilerin erkekler olduğuna dikkat çekerek kadınlara sembolik roller verildiğini dile getiriler (Çağlayan, 2007:23). Tanıl Bora bu durumu şöyle özetler: "milliyetçi söylem, kadın-özneden doğru ve kadın-özne varsayarak konuşmaz; kadınlar hakkında, kadınlara hitaben, erkek-biz 'den konuşur"' (Bora, 2005:271).

Nira Yuval-Davis, pek çok milliyetçilik kuramcısının milliyetçi ideolojilerin yeniden üretilmesinde entelektüellerin rolüne vurgu yaptığını, halbuki milletleri biyolojik, kültürel ve sembolik olarak yeniden üretenlerin entelijensiya değil, kadınlar olduğunu iddia eder (Yuval-Davis, 2007:19). Kadınların milliyetçiliğe dair çözümlemelerde neden görmezden gelindiği sorusuna ise Carole Pateman ve Rebecca Grant'in varsayımları üzerinden yanit arar.

Peteman'e göre batının toplumsal ve siyasal düzeninin temellerini atan "toplumsal sözleşme"yle ilgili klasik teoriler sivil toplumu kamusal ve özel alan olarak ikiye bölmüştür. Bu bölünmede kadınlara (ve aileye) siyasi olarak önemsiz olduğu düşünülen özel alan uygun görülmüştür. Pek çok düşünür tarafından milliyetçilik, kamusal siyaset alanın bir parçası olarak tartışılageldiği için de kadınlar bu alandan ve tartışmalardan dışlanmışlardır (akt. Yuval-Davis, 2007:19-20).

Grant ise kadınların siyasi alanın ve bu alan üzerine yapılan tartışmaların dışında tutulmasına kuruluş teorilerine yaslanarak bir açıklama getirir. Ona göre Hobbes ve Rousseau, doğal düzenden düzenli topluma geçişi erkeğin saldırgan doğası (Hobbes) ve erkeğin akıl kapasitesi (Rousseau) açısından betimlerler. Dolayısıyla kadınlar, bu geçiş sürecinin bir parçası değildirler. Tam da bu nedenle toplumsaldan dışlanarak "doğal"a yakın bir pozisyonda tahayyül edilirler (akt. Yuval-Davis, 2007:20). 
Milliyetçilik analizlerinde kadınların göz önünde tutulmamaları, tutulsalar dahi edilgen rollere hapsedilmeleri hususunda söz alan Chatterjee'de milliyetçi ideolojide kadınların "hakkında konuşulanlar" olarak sabitlenmesini, kamusal/özel alan ayrımına benzer bir ayrım çerçevesinde açıklar(Chatterjee, 2009:101). Ona göre özellikle batılı olmayan milliyetçi söylemde modernleşmeye bir sınır getirilmiştir. Kültür sahasını maddi ve manevi olmak üzere ikiye ayıran bu söylem, ev ve kadını "kirletilmemiş" manevi alanda konumlandırır. Batı uygarlı̆̆ının bilim, teknoloji, iktisadi örgütlenme gibi güçlerini kanıtladığı yer ise maddi alandır. Doğu, batı ile arasındaki ayrımı ortaya koymak için hayatın maddi olmayan yönlerini muhafaza etmenin gerekliliğine inanır. Çünkü manevi dünyada doğu, batıdan üstündür. Milliyetçi projenin eksiksiz bir biçimde tamamlanması için yapılması gereken "bir yandan ileri batı uygarlığının maddi tekniklerinden yararlanmak, bir yandan da ulusal kültürün kendisine has manevi özünü koruyup güçlendirmeye çalışmaktır (Chatterjee, 2009:108). Dolayısıyla maddi ve manevi hayatların her alanıyla ilişkilendirilen milliyetçiliğin, salt siyasi bir ideoloji olarak kavranamayacağı açıktır. Gündelik yaşamda bu maddi/manevi ayrımı, karşılığını iç ve dış, ev ve dünya ayrımı olarak bulur. Ev, manevi benliğimizi, gerçek kimliğimizi temsil ederken dünya, maddi çıarlar peşinde koşulan, pratik kaygıların belirleyici olduğu, tuzaklarla dolu ve yanı sıra erkeklerin hükmü altındaki bir alandır. Maddi dünyanın etkisiyle kirlenmemesi gereken evi kadın temsil eder (Chatterjee, 2009:109-110). Bu anlayıştan hareketle Doğu'da modern toplumun yeni kadını, yeni bir ataerkil düzene boyun eğdirilir (Chatterjee, 2002:211-212). Bu düzende kadın, tanrıça ya da ana olarak kutsallaştırılır. Bu kutsallaştırma kadına uygulanan tahakkümü meşrulaştırır. Ulusun bir simgesi biçiminde vazife gören kadının, fedakârlık, yardımseverlik, sadakat gibi ölümsüz değerleri temsil etmeleri Najmabadi'ye göre modernist tahayyülde kadınlara ilişkin bir söylemi, koruma ve sahiplenme söylemini pekiştirmiştir. Dolayısıyla milliyetçi söylemde kadınlar, erkeklerin koruyup sahiplenmesine muhtaç varlıklardır (Chatterjee, 2009:163).

Tüm bunlardan hareketle söyleyebiliriz ki, milliyetçiliğin kamusal/özel, kültür/doğa, ev/dünya dikotomileri üzerinden biçimlendirdiği cinsiyet ilişkileri çerçevesi, her türlü milliyetçilik kurgusunda başattır.

YIL: 5 SAYI: 10 
Dolayısıyla toplumsal cinsiyet milliyetçi kurgularda tali değil, kurucu bir rol üstlenir. Zira milliyetçilik gibi toplumsal cinsiyet rolleri de kurgusaldır. Bu nedenle bu iki alan, karşılıklı ve devamlı bir ilişki içerisinde birbirlerini beslerler.

Modern milliyetçi kurgularda ulustan aile metaforu temelinde bahsedilir. "Ulus kadınlar ve erkeklerin 'doğal' rollerini oynadıkları, başında erkek bir 'reis" bulunan bir ailedir" (Nagel, 2009:84). Aile, doğal bir birliktelik modeli içerdiği için, ulusu oluşturan kişiler arasında bulunması istenen ya da bulunduğu varsayılan bağ temsil eder (Sirman, 2009:232). Ulusun vatandaşları, tıpkı ailelerine olan sevgi ve bağlılıkları gibi bir duyguyu uluslarına karşıda geliştirmelidirler. Ulusun birlik ve beraberliği ancak bu aileye olan inanç ve bağlllıkla sağlanır. Ortak bir geçmişe ve ortak bir kadere sahip olduğuna inanılan bu geniş aile içerisindeki rol dağılımı, bizi doğrudan kurgulanmış toplumsal cinsiyet ilişkilerine götürür. Aile içindeki annelik, kız kardeşlik, kız çocukluk gibi roller, ulusun korunmasına dair anlatı ve söylemlerde merkezi bir yer işgal ederler.

Najmabadi'ye göre ulus, cinsiyetsiz, nötr bir kendilik değildir. Erkek kardeşlerin kurduğu, erkeklerin birliğine dayanan bir topluluk olup, aile imgesiyle somutlaştırılmış veya erkeklik imgesiyle cinsiyetlendirilmiş bir kavram olarak, milliyetçi anlatılarda en çok başvurulan mefhumdur. Bir erkek olarak ulusun, uğruna savaşacağı toprak ise dişidir. Dolaysıyla milliyetçi tahayyülde kadınları koruma ve sahiplenme söylemi, onların vatan toprağı olarak simgeselleştirilmesi ile daha da güçlenir. Zira milliyetçi kurgularda ulusun erkek, vatanın ise kadın olarak tahayyül edilmesi, erkelerin vatanı bir çeşit namus meselesi olarak kodlamalarına yol açar. Najmabadi, ulus (erke) ile vatan (kadın bedeni) arasında erotize bir ilişki olduğunu tespit eder(Najmabadi, 2009:129-130). Sevilen kadın olarak vatan imgesi, yabancıların taciz ve tecavüzüne karşı korunmalıdır. Bu namus bekçiliğini yapacak olansa şüphesiz ulus, yani erkektir. Kadınların namuslarına dair bir utanç unsuru, ulusu tehdit eder. Toprak kaybı, sevdiği kadının namusunu koruyamayan bir erkeğin utancına benzer bir duygu yaratır (Najmabadi, 2009:132-133). Tam da bu nedenle kadın cinselliği milliyetçilerin ilgi alanına girer. "Ulusun mikrokozmosu olan ataerkil aile, kadınların davranışlarını yönlendirir, çünkü ancak kadınların cinselliği- 
nin kontrol edilmesi, soyun saflığını ve ailenin namusunu garanti altına alır" (Cockburn, 2004:73). Deniz Kandiyoti, milliyetçi kurgularda vatanın korunması gereken bir kadın olarak simgeselleştirilmesinin beraberinde kadınların sırtlarına yüklenen "cinsel davranışları üzerinde bir öz bilinç ve denetim kurma" sorumluluğunu getirdiğine vurgu yapar (Kandiyoti, 2007:163). Kadınların eşler ve kızlar olarak erkeklerin, ulusun namusunun taşıyıcıları olmaları, onların cinselliğinin milliyetçilerin ilgi alanına girmelerinin sebebidir (Nagel, 2009: 86). Ayrıca ulusal imgeleri şekillendiren bir gösterge olarak kadının vatan ile özdeşleştirilmesi, içerisinde hem romantik hem de erotik yan anlamlar barındırır. Vatan/kadın için duyulan arzu; ona sahip olmak, hayran olmak, onu sevmek, korumak, onun uğruna ölmek gibi duygularda somutluk kazanan bir erkek arzusudur (Saigol, 2009:232)

Vatanın tahayyül edilişinde kadının, özellikle "anne" olarak kadının kullanılması, vatan toprağına karşı güçlü duyguların inşa edilmesinde son derece işlevseldir. Çünkü kadın, annelik konumu ile evlatlar arası, bir birlik ve bütünlük duygusu uyandırır. Böylece anne figürü, ulusu birleştiren ebedi, sabırlı ve vazgeçilmez bir bağlılık nesnesi olarak karşımıza çıkar. Kadınların bu şekilde simgeselleştirlmesi son derece güçlü ve yüceltici görünmesine rağmen, gerçek anne ve kadınların milletin eşitsizliğe uğrayan mensupları olması, ulus devletlerde ikinci sınıf vatandaşlar olarak muamele görmeleri Saigol'e ironik gelir (Saigol, 2009:234). Tanıl Bora bu ironiyi şöyle değerlendirir: "Kadın imgesinin milliyetçi kullanımı güya bir yüceltidir ama kadının bedenini ve kimliğini milleti kutsama pahasına araçsallaştırarak temellük eden bir yücelti” (Saigol, 2009:218). Ev dışındaki dünyanın "erkek" oluşu nedeniyle, kadınlar bu alanda erkekleşirler (Nagel, 2009:92).

Milliyetçi projelerde sesi duyulan ve kayıtlara geçenlerin erkekler olduklarını feminizmin katkıları ile yeni yeni fark edilmeye başlandığına değinen Cynthia Enloe, milliyetçiliğin erkekleştirilmiş hafıza, erkekleştirilmiş aşağılama ve erkekleştirilmiş umuttan doğduğunu söylerken, kadınların küçük, sembolik rollere indirgendiğinin altını çizer. Ona göre kadınlar ya ulusun korunup yüceltilecek ikonları ya da ele geçirilip aşağılanacak savaş ganimetleri olarak nesneleştirilirler. Her durumda gerçek aktörler, 
özgürlüklerini, namus ve şereflerini, vatanlarını ve kadınlarını koruyan erkelerdir (akt. Nagel, 2009:68).

Kadınların milliyetçi kurguların içerisinde cinsiyetçi bir biçimde konumlandırılmasında semboller merkezi bir yer işgal eder. Yuval-Davis, etnik ya da ulusal ideoloji ve pratiklerde kadınlara yüklenen sembolik rolleri şöyle sınıflandırır (akt. Çağlayan, 2007:23):

Etnik topluluğun üyelerinin yeniden üreticileri, anneler,

Topluluğun ideolojik yeniden üretiminde kültür aktarıcıları,

Etnik ve ulusal farkl1lıkların gösterenleri, etnik ve ulusal kategorilerin dönüşümü, yeniden üretimi ve inşasında kullanılan ideolojik ve söylemlerin merkezinde yer alan semboller,

Etnik ve ulusal grupların sınırlarının yeniden üreticileri ve

Ulusal, ekonomik, politik ve askeri mücadelelerde bizzat katılımcılar

Bu sınıflandırma makale için temel bir referans noktası teşkil etmektedir. Çalışmada yol gösterici olması açısından milliyetçi söylem içerisinde kadına yüklenen bu sembolik rollerin detaylandırılması yerinde olacaktır.

\subsection{Milletin Biyolojik Yeniden üreticisi Olarak Kadın}

Milliyetçi ideolojide kadının rolü daha çok annelikle ilgilidir ve değeri bu role göre ölçülür. Çünkü ulusun varlığını sürdürebilmesi ve ulus bazında diğerlerine karşı üstünlük sağlayabilmek için çocuk sahibi olacak kadınlara ihtiyaç vardır. Kadınların kucaklarında çocukları ve ellerinde silahlarla resmedildikleri milli anlatılara atıfta bulunan Cockburn, kad1nın milliyetçi söylemindeki değerinin, "ulusun ruhu"nu simgelemesinden kaynaklandığına işaret eder (Cockburn, 2004:73). Saigol de kadınların ulus devlete birincil giriş noktasının, anne olmaları, kutsal vatan toprağı uğruna canını feda edebilecek yürekli oğullar doğurup yetiştirmeleri olduğunu söyler (Saigol, 2009:235).

Kadınların anne olup olmamayı ya da kaç çocuğa ne zaman sahip olacağını seçme haklarına ilişkin tartışmalar feminist mücadelenin günde- 


\section{$264 \cdot$ YALOVA SOSYAL BILIMLER DERGISI}

minde ezelden beri önemli bir yer işgal etmektedir. Ancak bu tartışmalar daha çok kadınların sağlığı, iş yaşamı, sınıfsal konumları ve aile yaşamları çerçevesinde yapılmıştır. Halbuki çocuk sahibi olup olmama yönünde kadınlara yapılan baskılar daha çok belirli bir milli topluluğun üyesi olmakla ilgilidir (Yuval-Davis, 2007:54). Kadınların içinde yaşadıkları etnik ve milli topluluklarda veya vatandaşı oldukları devletlerde anneler olarak kodlanıyor olmaları, düzenleyicilerin onların üreme hakları üzerinde söz söyleyebilme ve tasarruf sahibi olabilme hakkını meşrulaştırır.

Özellikle ırkçı topluluklarda, ırkın "saflığı" meselesi üzerinden topluluğun üyeleri arasındaki cinsel ilişkiler dahi kontrol altında tutulmaya çalışılır. Milliyetçi ideolojiler evliliğin, döllenmenin ve dolayısı ile cinselliğin denetlenmesi yönünde hayli çaba sarfederler. Bu çabanın nedeni, soy karışımı korkusudur. Örneğin İsrail'de milliyetçi bir lider parlamentoya sunduğu bir yasa teklifinde Yahudiler ile Araplar arasında cinsel ilişkinin yasaklanmasını talep etmiştir. Benzer şekilde İsrail'de taşıyıcı anneliğe ilişkin kanuna göre taşıyıcı anne ile gerçek annenin aynı dine mensup olmaları gerektiği belirtilir. Bu talepler şüphesiz arklar arası cinsel ilişki vasıtasıyla doğabilecek çocukların, Yahudilerin "saf kan"ını bozacağına ve buna bağlı ayrımcılığa son vermek üzere harekete geçen Güney Afrika hükümetinin bu yönde izlediği temel politikalardan biri farklı ırklara mensup insanların cinsel ilişkiye girmesinin ve evlenmelerinin önünü açan bir yasa hazırlamak olmuştur (Yuval-Davis, 2007:62-65)

Yuval-Davis, milli projelerde milliyetçi nüfus politikalarının işleyişinin nasıl olduğu hususunda ise üç temel söylemin belirleyici olduğunu söyler. Onun "iktidar olarak halk söylemi” adıyla kavramsallaştırdığ ilk söylem biçimi (pronatalist söylem), milli topluluğun nüfusunun korunması ve genişletilmesini milli çıkarlar için hayati görür (Yuval-Davis, 2007:67). Milletin bekasını, onun sürekli büyümesine bağlayan bu söylem çerçevesinde hükümetler çocuklu ailelere teşvik amacıyla düzenli olarak belli miktarlarda para ödülleri sunmaktadırlar. Örneğin, Japonya' da nüfusun azalmasının önüne geçebilmek için aileler televizyon reklamları aracılığıyla çocuk yapmaya teşvik edilmektedirler. Benzer biçimde Yahudi kadınlar çocuk ödenekleri, doğum izni gibi teşvik yöntemleri ile ya da özellikle ülkenin kuruluş yıllarında on ve ondan fazla çocuk sahibi olanlar

YIL: 5 SAYI: 10 
"kahraman anneler" olarak nitelendirilip ödüllendirilmişlerdir. İsrail'de çocuk sahibi olamamak veya Yahudi ırkı dışındaki ırklara mensup olanlarla evlenmek "demografik soykırım"a bir katkı olarak görülmektedir (Yuval-Davis, 2007:69).

Ülkelerin demografik olarak büyüme talebi, bazen dış göçün araçsallaştırılması ile de sağlanabilmektedir. Avustralya örneği bu durumun somut bir yansımasıdır: Oradaki "millet yaratma" sürecinin yaşayabilmesi için halkın belli bir "kritik" sayıda olmasının hayati olduğu düşünülmektedir. Bu hedefi gerçekleştirmenin hızlı bir yolu olarak dışarıdan göç teşvik edilmekte, ancak "sarı tehlike" olarak yorumlanan Asyalılar gibi "istenmeyen öğeler"i dışarıda tutacak önlemler baştan alınmaktadır (Yuval-Davis, 2007:67).

Milliyetçi nüfus politikalarının işleyişinde kullanılan bir diğer söylem öjenizmdir. Nüfusun çokluğu ile değil, kalitesi ile ilgilenen bu "sahte bilim"in en uç noktada uygulanışı Nazi Almanya'sında görülmüştür. Naziler "bazı" Alman kadınları çocuk sahibi olmaya zorlarken "bazı"larını ise zor yoluyla bu haktan mahrum bırakmışlardır. Öjenist söylemin bir göstergesi olan bu tutumun dayandığı nokta Adolf Hitler'in ifadesiyle şöyledir; "Erkeklerin kadınlar için mücadelesi, sadece en sağlıklılara çoğalma hakkını veya firsatını verir" (akt. Yuval-Davis, 2007:70-71) Günümüzde bu söylemin en somut hali ile işlediği ülke Singapur'dur. Singapur başbakan1, özellikle yüksek eğitimli kadınlardan bir "vatanseverlik görevi” olarak genetik açıdan üstün çocuklar doğurmalarını istemiş, yoksun ve eğitimsiz kadınlara ise çocuk doğurmamalarını telkin etmiş, dahası kısırlaştırılmayı kabul etmeleri yönünde onlara talimat vermiş, vermekle kalmamış teşvik etmiştir. Zira kısırlaşmayı kabul eden kadınları 10.000 dolarlık ödül beklemektedir. Yuval-Davis bu örneğin dışında da -her zaman bu kadar aleni olmamakla birlikte- dünyanın hemen hemen her yerinde farklı biçimlerde nüfusun belli katmanlarına çocuk doğurmayı teşvik ve caydırma politikalarının uygulandığını iddia eder (Yuval-Davis, 2007:72)

Milliyetçi bir diğer nüfus politikası ise, Malthusçu söylemin sınırları içindedir. Bu söylem büyümesinin aksine, kontrolsüz nüfus artışının ülkeye felaket getireceği varsayarak kadınları çocuk yapmaktan caydırma amacı ile iş görür. Bu "sadece ideolojik bir söylem olmayıp, birçok Üçüncü 
Dünya ülkesinde, ülkenin ekonomik ve toplumsal sorunlarını çözmede temel bir strateji olarak nüfus politikalarının mihenk taşı haline gelmiştir (Yuval-Davis, 2007:73). "Kontrol edilemez" nüfus artışının bir sonucu olarak işgücü arzı ve talebi arasındaki denge ciddi biçimde tehdit edildiği takdirde, ekonomik ve politik sistemin istikrarsızlaşması korkusu mevcuttur. Bu söylemin radikal örneklerinden birimine rastladığımız Brezilya'da 1990'ların sonunda, gecekondu mahallelerinde, kadınların rahmi zorla al1narak kısırlaştırma yoluna gidilmiştir. Bu proje, Dünya Bankası fonlarıyla desteklenmiştir. Kısırlaştırılan birçok kadına, rahimleri alınacağı ve ömür boyu çocuk doğuramayacakları söylenmemiştir. Birçok kadın bu operasyonlar sırasında sakatlanmıştır. Çin'de ise çocuk sahibi olmaya belirli yasal kısıtlamalar getirilmiş olup, bu kısıtlamalara uymayan ebeveynlere işsiz bırakılma cezası, çocuklarına ise eğitimden mahrum edilme cezas1 uygulanmaktadır. Malthusçu politikaların annelerin yanı sıra, çocuklar üzerinde de son derece cinsiyetçi uygulamalara yol açtığı görülmektedir. Çeşitli toplumsal ve ekonomik nedenlerle erkek çocuklara daha fazla değer verilirken kürtaj ve bebek cinayetlerinin kurbanlarının daha çok kız bebekler olması, bu durumun yansımasidır (Yuval-Davis, 2007:75).

Tüm bu söylemler ve politikalar günümüz siyasetinin içinde, hatta merkezinde yer almaktadır. Türkiye'de bu söylemin dönem dönem siyasi iktidar sahipleri tarafından özellikle milliyetçi projelerin bir parçası olarak kullanıldığı görülmektedir. Türkiye'de cumhuriyet sonrası dönemlerde uygulanan nüfus politikaları ve bugünkü siyasal iktidarın gündeminde olan 3 ve daha fazla çocuk sahibi olanlar için para yardımı yapılacağı ifade edilmekte ve bu yönde çalışmaların devam ettiği belirtilmektedir.

Kadınların cinselliğine ulusal hedefler için el konulması, onların bedenleri üzerindeki kontrolü de ellerinde almak anlamına gelir. Kadınların kendi bedenlerini ve cinselliklerini kontrol etmeleri, bilhassa milliyetçi tahayyülde bir tehdit olarak algılanmaktadır. Onların milli ve etnik gruplara üyeliği sırf kadın oluşlarından ötürü özel kurallar ve düzenlemelere tabi olmalarını haklı çıkarmaktadır (Yuval-Davis, 2007:80). Üstelik kadınlar, milliyetçi söylemde yalnızca annelik rolleri ile değil, aynı zamanda kültürün gösterenleri ve taşıyıcıları olarak da hem simgesel hem de somut bir tahakküm hedefidirler.

YIL: 5 SAYI: 10 


\subsection{Milli Kültürün Göstereni ve Aktarıcısı Olarak Kadın}

Pek çok milli projenin rotasını bir yandan modernleşmeci bir motivasyonla belirlediği, diğer yandansa o topluma özgü kültürel özellikleri korumanın ve böylece diğer milletlerden "fark"ını ortaya koymanın önemini vurguladığını ifade etmiştik. Bahsi geçen fark, kültürün belirli simgesel gösterenler aracılığı ile görünür kılınması ve aktarılmasıyla sağlanabilir. Milliyetçilik, ait olunan milletin öz kültürünü koruma, gösterme ve onu gelecek nesillere aktarma görevini kadınlara, annelere verir.

Giddens'a göre kültür, bir grubun üyelerinin inandıkları değerlerden, isledikleri normlardan ve yarattıkları maddi şeylerden oluşan bir yaşam biçimidir (Giddens, 2000:78). Bu haliyle kültürün "bizi ötekilerden ayırt eden özellikler” olarak tanımlanması milliyetçi söylem açısından elzemdir. Zira milliyetçi söylem, genelde bir "öteki” ya da "düşman" tahayyülü üzerinden güç kazanır. "Biz"i öteki üzerinden kuran bu zihniyet, biz algısına dahil olamayan tüm unsurları milli birlik ve bütünlüğe bir tehdit olarak görüp dışarıda konumlandırır. Milli birliğin devamına ise milli kültürün devamıyla koşut görür. Kültürün en temel özelliği, tarihsel ve maddi koşullar değişse de sürekli yeniden üretilmesi sayesinde bir ölçüde dayanıklılığa sahip olmasıdır. İşte bu dayanıklılık, ancak kültürün nesilden nesle aktarılmasıyla mümkündür. Kadın, milliyetçi söylemin alanına tam da bu görevi yerine getirmek üzere tayin edilir. Hobsbawm'ın da öne sürdüğü üzere, bir milletin kurgulanması için topluluğa ilişkin belli geleneklerin ve ayırt edici özelliklerin icat edilmesi ve sürekli olarak yeniden üretilmesi gerekir (Yuval-Davis, 2007:96). İşte milliyetçi tahayyülde kültürel geleneklerin nesiller arası aktarıcısı olarak simgeleştirilen figürler kadınlardır. $\mathrm{Bu}$ simgeleştirme, kadınlar üzerinde kurulan tahakkümü de meşrulaştırıcı bir işlev görmektedir.

Kültürel alanda bir milletin farklılığının en büyük göstereni olarak belirtilen kadın, bir temsil yükü ile karşı karşıya kalır. Bu temsil yükü, kadınların topluluğun namusunun taşıyıcıları olarak kurulmalarını da beraberinde getirir. Milliyetçi söylemin kadının öznelliğine müdahale edişinin meşruluk zemini buradadır. Kadın kıyafeti ile davranış biçimi ile bir milleti diğerlerinden farklılaştıran bir rol üstlenir. "Uygun” davranışlar 
içindeki kadınlar ve "uygun" giysileri, topluluğun sınırlarını gösteren çizgiyi somutlaştırmaktadır. Bu yüzden kolektif namusu "kirleten" kadınlar, çeşitli biçimlerde cezalandırılırlar. Örneğin İsrailli bir kadın, batılı giyim tarzı, makyaj ve boyalı saçları ile bir TV kanalına röportaj verdiği için erkek kardeşi tarafından öldürülmüştür. Gerekçe olarak da ailesi tarafından kadının "çizgiyi aştı̆̆ı" ve kültürünü koruyamadığı öne sürtülmüştür (Yuval-Davis, 2007:95).

\subsection{Milliyetçi mücadelenin katılımcısı olarak kadın}

Kadınlar, milliyetçi kurgularda yalnızca kendilerine yüklenen sembolik rollerle değil, zaman zaman milliyetçi mücadelelerin katılımcıları olarak da varlık gösterirler. Ancak ordu ve savaş mantığının eril karakteri düşünüldüğünde, pek çok milliyetçi anlatının mücadeleye dâhil olan kadınları daha çok durumun duygusal boyutunu manipüle etmek amaciyla kullanıldığ görülür.

Yuval-Davis orduların ve savaşların yalnızca erkek bölgesi olmadığını, kadınların bu mücadelelerin içinde -erkeklerin rolleri ile eşit olmasa da- belli rolleri yerine getirdiklerini söyler. Ona göre toplumsal ayrımlarda erkeklerin savaşçılar, kadınların ise "kaygılananlar" olarak kuruluşlarının doğallaştırılması, kadının daha çok barışı simgeler bir tarzda düşünülmesinin bir sonucudur (Yuval-Davis, 2007:176). Feminist literatürde de kadınların orduya katılımları üzerine temel bir tartı̧̧ma mevcuttur. Bir kısım feminist, kadınların ordudan dışlanışının onların doğallaştırılmış toplumsal cinsiyet rollerini pekiştirdiğini ve eşitlik adına orduya resmi katılımlarının gerekli olduğunu savunur. Halbuki kadınlar mücadeleye doğrudan katılmasalar da ölü ve yaralılara göz kulak olarak ya da kazanan tarafın beden bulan mülkiyeti haline gelerek zaten onun bir parçası olurlar. Ama bu durum, onların toplumsal olarak kabul edilmiş cinsiyet rollerini pekiştirmekten öte birşey sağlamaz (Yuval-Davis, 2007:178). Örneğin, düzenli olarak askere alınan İsrail ordusundaki kadınların resmi görevlerinden biri de "birimlerin moralini düzeltme ve birimlerdeki askerle göz kulak olma" dır (Yuval-Davis, 2007:189). Aslında bu durum, kadınların orduya dâhil edilse bile yalnızca destekleyici roller bazında görevlendirildiklerinin bir göstergesidir.

YIL: 5 SAYI: 10 
Yuval-Davis, asker olmanın kadınlar için potansiyel faydalarını tartışırken, ordunun nihai işlevinin savaşmak olduğunun unutulduğuna dikkat çeker (Yuval-Davis, 2007:189). Tam da bu nedenle tartışmanın karşı tarafı kadınların orduya girişinin bir hak ve eşitlik mücadelesi olarak değerlendirilmesi gerektiğini reddeden feministlerden oluşur. Bir yönüyle zorunlu askerlik uygulamasının erkek ve kadınların devletle aralarındaki vatandaşlık iliş̧isini belirleyen ve kadınlar asker olmadıkları için onları farklılaştıran bir yanı vardır. Diğer yandan ise savaşların ve askerlerin ulus devlet projelerinin ve milliyetçiliğin doğal uzantıları olduğu fikrinden hareketle, zaten bu projelerin söyleminde son derce nesneleştirilmiş ve ötekileştirilmiş olan kadınların asker olma hakkının nasıl bir kazanım olacağı tartışılması gereken bir noktadır. Cynthia Enloe'nun bu konudaki uyarısı dikkate değerdir; orduya katılım her ne kadar kadınlar açısından bir hak olarak görülse de, orduların varlığı ve etkinliklerinin kadınlar üzerindeki etkilerini görmezden gelmek mümkün değildir (akt. Altınay, 2009:290) Enloe bir yandan da, pek çok kadının milliyetçi hareketlere katılımla ev içi alandan kurtulup kendisine kamusal yaşamda bir yer edinildiğini vurgular (Enloe, 2009:205). Bu nedenle sürecin aynı zamanda ataerkini zayıflatan sonuçlarına odaklanmak gerektiğini söyler. Ona göre "kadınlar, kazanılan hakları ataerkil milliyetçi erkeklere değil onlara rağmen elde etmiş̧lerdir" (Enloe, 2009:205). Ancak yine de pek çok yazar, kadın milliyetçilerin daha çok destekleyici, sembolik ve geleneksel rollerde kalmaları yönünde bir baskı hissettiklerinde hemfikirdir: Bu kısıtlamalarla yüz yüze olan kadınlar, kimi zaman milliyetçiliklerini, kendilerine milliyetçiler tarafından yüklenen geleneksel roller yoluyla gerçekleştirmeye yeltenirler -kocasina destek vererek, çocuklarını (ulusun çocuklarını) yetiştirerek ve ulusun namusunun simgeleri olarak hizmet ederek" (Nagel, 2009:81).

Milliyetçi söylemde kadınlara yüklenen anlamlar ve verilen roller çerçevesinde yürütülen tüm bu tartı̧̧malar, milliyetçi kimliğin ortaya koyulması açısından bir kuramsal dayanak oluşturmaktadır. Ancak bu tartışmalar toplumsal cinsiyetin milliyetçilik olgusu ile karşıllıklı etkileşimini ortaya koymalarına rağmen en büyük eksiklikleri kadınlık kimliğini statik bir kavram olarak ele almalarıdır. Kimliğe, milliyetçi söylem tarafından oluşturulmuş bir sonuç olarak bakılması onun değişime açık, inşai bir 


\section{$270 \cdot$ YALOVA SOSYAL BILIMLER DERGISI}

süreç olarak kavranmasını olanaksız kılar (Sirman, 2009:230-231). Bu yaklaşım tek başına baz alındığında hem söylemsel düzeydeki hem de günlük hayattaki değişiklikler göz ardı edilir. Milliyetçi söylemin kurduğu toplumsal cinsiyet kimliklerin özneler tarafindan nasıl üstlenildiği bir soru işareti olarak kalır.

\section{Sonuç}

Son dönemlerde değişik disiplinler açısından ele alınarak incelenen ve tartış1lan toplumsal cinsiyet ve milliyetçilik ilişkisi dikkat çeken bir araştırma konusu haline gelmiştir. Millet ve milliyetçiliğe dair çözümlemelerde uzun bir süre görmezden gelinen toplumsal cinsiyet farklılıklarının ve kadın kimliğinin millet ve milliyetçiliklerin inşa süreçlerine katk1ları, üstlendikleri roller yapılan çalışmalarla ortaya konmaktadır.

Kadın ve erkeğin doğasında olmayan, doğuştan gelmeyip sonradan toplumsal yaşantı içinde oluşan farklılıklar, beraberinde toplumsal cinsiyet tartı̧̧alarını da getirmiştir. Toplumsal cinsiyet ile cinsiyet kimliği arasında oluşan farklılıklar, kadın ve erkek arasındaki biyolojik ayrımdan farklı olarak "kadınlık" ve "erkeklik" kategorilerinin toplumsal oluşumu toplumsal cinsiyet kavramını tartışmaların merkezine taşımıştır. Kadının öznel alanın öznesi olma durumu, dünyada sosyal, ekonomik ve düşünsel alanlarda yaşanan gelişmelerin sonucunda giderek değişime uğramıştır. Bugün gelinen noktada kadınlar sosyal, ekonomik, kültürel ve ticari alanlarda önemli görevler üstlenerek yeteneklerini kanıtlamışlardır.

Toplumsal cinsiyet farklılıkları, kadın ve erkeğin toplumdaki konumları genel olarak toplumun değer sistemi ve yapısıyla ilişkilidir. Bu açıdan baktı̆̆ımızda hemen hemen bütün toplumların geleneksel yapılarının modernleşme süreci içerisinde değiştiği söylenebilir. Bu genel değişim kadın ve erkeğin konumundaki değişmelerin yanı sıra toplumdaki diğer ögelerin de değişimini kapsamaktadır.

$\mathrm{Bu}$ bağlamda çalışma, toplumsal cinsiyet ve milliyetçilik olgusunun tarihsel süreç içerisinde geçirdiği değişimleri ve onu şekillendiren unsurları irdelemek amacıyla yapılmıştır. Makalede, toplumsal cinsiyet ve

YIL: 5 SAYI: 10 
milliyetçilik konusundaki kavramlar ve yapılan çalışmalar metodolojik olarak incelenmiş; milliyetçi projelerin toplumsal cinsiyetçi kurgulara dayandığg, milliyetçilik hareketlerinde kadın kimliğinin özel alanda yalnızca iyi bir eş ve anne olmanın ötesinde milli kültürün göstereni ve aktaranı olarak ve milliyetçi mücadelenin doğrudan katılımcısı olarak önemi ortaya konmuştur.

\section{Kaynakça}

Akal, C. Baki, (1994) Siyasi İktidarın Cinsiyeti, Ankara, İmge Kitabevi.

Ayata, G. A., (1996) Kent, Komşuluk ve Kent Kültürü, Ankara, Konut Araştırmaları Dizisi (TOKIP).

Beauvoir, S., (1993) Kadın “İkinci Cins” Genç Kızlık Çağı, İstanbul, Payel Yayınlar1.

Bora, T., (2005) Analar, Bacılar, Orospular: Türk Milliyetçi- Muhafazakâr Söyleminde Kadın. (A. Öncü, O. Tekelioğlu, Der.), Şerif Mardin'e Armağan (241-281), İstanbul, İletişim Yayınları.

Boyarin, D., Taylor, M. C., (1998) Gender, Critical Terms For Religious Studies. (Ed). The University Chicago Press, Chicago \& London.

Caner, E., (2004) Kutsal Fahişeden Bakire Meryem'e Toprak ve Kadın, İstanbul, Su Yayınları.

Chatterjee, P., (2002) Ulus ve Parçaları. (İ. Çekem, Çev.), İstanbul, İletişim Yayınlar1.

Chatterjee, P., (2009) “Kadın Sorununa Milliyetçi Çözüm”, (A. G. Altınay, Der.), Vatan Millet Kadınlar (103-127). İstanbul, İletişim Yayınları.

Connell, R. W., (1998) Toplumsal Cinsiyet ve İktidar, (Çev. C. Soydemir). İstanbul, Ayrıntı Yayınları.

Çağlayan, H., (2007) Analar, Yoldaşlar, Tanrıçalar: Kürt Hareketinde Kadınlar ve Kadın Kimliğinin Oluşumu, İstanbul, İletişim Yayınları. 
Donavan, J., (1997 ) Feminist Teori Amerika Feminizminin Entelektüel Gelenekleri, (çev. Bora, A. , Gevrek A. M., Sayılan), İstanbul, İletişim Yayınlar1.

GIDDENS, A., (2000), Elimizden Kaçıp Giden Dünya, (Çev. O. Akınhay ), İstanbul, Alfa Yayınları

Gökalp, Z., (2004). Türkçülüğü Esasları, (Yay. Haz. M. Ünlü, Y. Çotuksöken), İstanbul, İnk1lâp Yayınlar1.

Hartmann, H., (2006) Marksizm'le Feminizm'in Mutsuz Evliliği. İstanbul: Agora Kitaplı̆̆

Heckmann, L. and van Gelder, P., (2009) “90’larda Türkiye'de Siyasal Söylemin Dönüşümü Çerçevesinde Kürt Kadınlarının İmajı: Bazı Eleştirel Değerlendirmeler”, (A. G. Altınay, Der.), Vatan Millet Kadınlar (308338), İstanbul, İletişim Yayınları.

Hobsbawm, Eric J., (1995) 1780'den Günümüze Milletler ve Milliyetçilik, "Program, Mit, Gerçeklik", (çev. O. Akınhay), İstanbul, Ayrıntı Yayınları.

Illich, I., (1996) Gender, (Çev.: Ahmet Fethi), Ankara, Ayraç Yayınevi.

Kandiyoti, D., (2007) Cariyeler, Bacılar, Yurttaşlar, İstanbul, Metis Yayınları.

Kellas, J. G., (1991) The Politics of Nationalism and Ethnicity. MacMillan, Hong Kong.

Marcos, S., (2006) Bedenler Dinler ve Toplumsal Cinsiyet, (Çev: S., Özbudun, B.,Şafak, İ., Çayla), Ankara, Ütopya Yayınevi.

Marshall, G., (1999) Sosyoloji Sözlüğüu, (Çev: Akınhay, O., Kömürcü, D.), Ankara, Bilim ve Sanat yayınları.

Nagel, J., (2009) “Erkeklik ve Milliyetçilik: Ulusun İnşasında Toplumsal Cinsiyet ve Cinsellik", (A. G. Altınay, Der.), Vatan Millet Kadınlar (65-103). İstanbul, İletişim Yayınları.

Najmabadi, A., (2009) "Sevgili ve Ana Olarak Erotik Vatan: Sevmek, Sahiplenmek, Korunmak", (A. G. Altınay, Der.), Vatan Millet Kadınlar (129-167). İstanbul, İletişim Yayınları.

Özkırımlı, U., (2008) Milliyetçilik Kuramları: Eleştirel Bir Bakış, İstanbul, Doğu Batı Yayınları.

YIL: 5 SAYI: 10 
Saigol, R., (2009) "Militarizasyon, Ulus ve Toplumsal Cinsiyet: Şiddetli Çatışma Alanları Olarak Kadın Bedenleri”, (A. G. Altınay, Der.), Vatan Millet Kadınlar (227-259), İstanbul, İletişim Yayınları.

Schroeder, Süheyla, K., (2007) Popüler Feminizm, Türkiye'de ve Britanya'da Kadın Dergileri, İstanbul, Bağlam Yayıncılık.

Sirman, N., (2009) "Kadınların Milliyeti”, (T. Bora, M. Gültekingil, Ed.), Modern Türkiye'de Siyasi Düşünce: Milliyetçilik (226-244), İstanbul, İletişim Yayınları.

Smith, Anthony D., (1999), "Milliyetçilik ve Kültürel Kimlik", Türkiye Günlüğü, Say1 50, Mart-Nisan 1999, ss.77-101.

Smith, Anthony, D., (2001) “Milliyetçilik ve Tarihçiler”, (Çev: İsmail Türkmen), Tartışılan Sınırlar Değişen Milliyetçilik (31-63), ( Der, ARMAĞAN M.), İstanbul, Şehir Yayınları.

Stanley, L. ve Wise, S., (Tarihsiz) "Feminist araştırma sürecinde metot metodoloji ve epistemoloji”, (çev. F. Şaşmaz, Yay. Haz. S. Çakır, N. Akgökçe), Kadın Araştırmalarında Yöntem içinde, İstanbul, Sel Yayıncılık.

Stone, M., (2000) Tanrılar Kadınken, (Çev. Nilgün Şarman), İstanbul, Payel Yayınları.

Şişman, N., (2006) “Emanet”ten “Mülk”e Kadın Bedeninin Yeniden İnşası, İstanbul, İz Yayınc1lı.

Yıldırmaz, T., Y., (2005), Ütopyanın Kadınları, Kadınların Ütopyası, İstanbul, Sel Yayıncılık.

Yuval Davis, N., (2007) Cinsiyet ve Millet ( A. Bektaş, Çev.), İstanbul, İletişim Yayınları.

Zılfi, Madeline C., (Ed.), (2000) Modernleşmenin Eşiğinde Osmanlı Kadınları, İstanbul, Tarih Vakfi Yurt Yayınları.

Zoonen, V. L., (1994) Feminist Media Studies. Londo, Sage Publications. 